Jurnal Ilmu Sosial dan Pendidikan (JISIP)

Vol. 5 No. 3 Juli 2021

Terakreditasi Peringkat 5 (No. SK: 85/M/KPT/2020)

e-ISSN : 2656-6753, p-ISSN: 2598-9944

DOI: 10.36312/jisip.v5i3.2192 /http://ejournal.mandalanursa.org/index.php/JISIP/index

\title{
Analisis Yuridis Pengaturan Sanksi Bagi Penolak Vaksinasi Covid-19
}

\author{
${ }^{1}$ Yulia Emma Sigalingging, ${ }^{2}$ Aris Prio Agus Santoso
}

${ }^{1}$ Fakultas Hukum dan Komunikasi Universitas Katolik Soegijapranata Semarang

${ }^{2}$ Fakultas Hukum dan Bisnis Universitas Duta Bangsa Surakarta

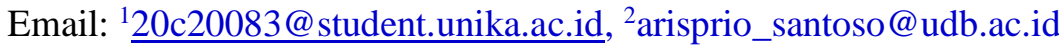

\begin{tabular}{l}
\hline \hline Article Info \\
Article history: \\
Article Accepted: 09 July 2021 \\
Publication : 16 July 2021 \\
\end{tabular}

\section{Keywords:}

Setting sanctions, covid-19 vaccination.

\begin{tabular}{l}
\hline Article Info \\
\hline Article history: \\
Article Accepted: 09 July 2021 \\
Publication : 16 July 2021
\end{tabular}

\section{Kata Kunci:}

Pengaturan Sanksi, Vaksinasi Covid-19.

\begin{abstract}
Referring to Article $28 H$ paragraph (1) of the 1945 Constitution, the Government has tried to ensure the health of its citizens through the Covid-19 Vaccination program, but there are still people who refuse to be given the Covid-19 vaccination, and this has become a pro and con in the community. The formulation of the problem in this study is how to set sanctions for refusal of Covid-19 vaccination and how the right to refuse the Covid-19 vaccination is viewed from the point of view of Human Rights.nThis research method uses a normative juridical approach, with data collection from literature studies. The data obtained were analyzed qualitatively. Based on the results of the study, it was found that the sanctions for refusing the Covid-19 vaccine were in the form of imprisonment of 6 months to 1 year in prison or a fine of $R p .500,000-R p$. 1,000,000. In addition, there are sanctions in the form of delaying or discontinuing the provision of social security or social assistance, delaying or discontinuing government administrative services, and fines. In fact, refusing to be vaccinated against Covid-19 is a form of individual freedom that cannot be forced with all considerations to express his aspirations regarding the risks and consequences to his body. Where this should be respected by the Government as stated in Article 28J Paragraph (1) of the 1945 Constitution.
\end{abstract}

\begin{abstract}
Abstrak
Mengacu pada Pasal 28H ayat (1) UUD 1945,Pemerintah telah berupaya menjamin kesehatan bagi warga negaranya melalui program Vaksinasi Covid19 , namun masih terdapat masyarakat yang menolak diberikan vaksinasi Covid19, dan hal ini telah menjadi pro kontra di tengah-tengah masyarakat. Perumusan masalah dalam penelitian ini adalah bagaimana pengaturan sanksi bagi penolak vaksinasi Covid-19 dan bagaimana hak menolak vaksinasi Covid19 ditinjau dari sudut pandang HAM. Metode penelitian ini menggunakan pendekatan yuridis normatif, dengan pengumpulan data dari studi pustaka. Data yang diperoleh dianalisis secara kualitatif. Berdasarkan hasil penelitian ditemukan bahwa sanksi bagi penolak vaksin Covid-19 yaitu berupa penjara 6 bulan sampai 1 tahun penjara atau denda Rp. 500.000 - Rp. 1.000.000. Selain itu juga terdapat sanksi berupa penundaan atau penghentian pemberian jaminan sosial atau bantuan sosial, penundaan atau penghentian layanan administrasi pemerintahan, dan denda. Padahal, menolak vaksinasi Covid-19 merupakan bentuk kebebasan individu yang tidak bisa dipaksakan dengan segala pertimbangan untuk menyampaikan aspirasinya terhadap risiko dan konsekuensi terhadap tubuhnya. Di mana hal ini seharusnya dihormati oleh Pemerintah sebagaiana yang tertuang dalam Pasal 28J Ayat (1) UUD 1945.
\end{abstract}




\section{PENDAHULUAN}

Konstitusi negara Indonesia telah menjamin adanya jaminan kesehatan bagi warga negaranya, dengan terejawantahkan dalam Pasal 28H ayat (1) UUD NRI 1945. Artinya Pemerintah memiliki tanggung jawab untuk memperhatikan dan memberikan jaminan yang sesuai dengan amanat konstitusi. Karena warga negara Indonesia memiliki hak yang sama di mata hukum sesuai dengan Konsep Hak Asasi Manusia untuk memberikan keadilan dan mensejahterakan rakyatnya tanpa membeda-bedakan kelas sosial. Dengan adanya jaminan kesehatan yang diberikan oleh Pemerintah, maka jika terdapat permasalahan di negara ini seperti merebaknya Covid-19 dapat teratasi dengan adanya jaminan tersebut.

Di Indonesia kesadaran masyarakat masih rendah untuk mengikuti imbauan pemerintah dalam memotong mata rantai penyebaran Covid-19 yang terlihat dari masih banyaknya aktivitas masyarakat di luar rumah, padahal partisipasi masyarakat menjadi kunci utama untuk pencegahan penyebaran wabah Covid-19. Pemerintah sebenarnya telah menganjurkan masyarakat untuk menerapkan social distancing (pembatasan sosial) dan physical distancing (pembatasan fisik) guna memotong rantai penyebaran virus tersebut.

Partisipasi masyarakat dalam penanganan Covid-19 mempunyai peran yang sangat penting, masyarakat dapat berperan bukan saja sebagai objek tetapi juga sebagai subjek penangan an Covid19. Partisipasi masyarakat pada dasarnya merupakan kesediaan secara ikhlas dari masyarakat untuk membantu kegiatan penanganan penyakit yang terjadi di daerahnya masing-masing agar penyebaran Covid-19 ini tidak semakin meluas. Karena itu, masyarakat dengan kesadaran penuh seharusnya juga mengikuti program Pemerintah terkait dengan pemberian vaksinasi Covid-19 namun hal ini telah menjadi pro kontra di tengah-tengah masyarakat terkait pelaksanaan vaksinasi di Inodnesia. Sejumlah pihak mempertanyakan apakah vaksinasi untuk mayarakat merupakan hak ataukah kewajiban. Pemerintah melaluiWakil Menteri Hukum dan Hak Asasi Manusia menyampaikan bahwa vaksinasi Covid-19 merupakan bagian dari kewajiban seluruh warga negara untuk mewujudkan Kesehatan masyarakat, namun sejumlah aktivis pada bidang Hak Asasi Manusia tegas menyatakan bahwa menolak vaksin adalah hak asasi rakyat.

Kementerian Kesehatan bersama beberapa organisasi (II AGI, UNICEF dan WHO) melakukan survei daring pada 19-30 September 2020 untuk mengetahui penerimaan publik terhadap vaksin COVID-19. Survei tersebut melibatkan lebih dari 115.000 responsden dari 34 provinsi di Indonesia. Berdasarkan survei tersebut, diketahui bahwa 658 responsden bahwa bersedia menerima vaksin COVID-19 jika disediakan Pemerintah, sedangkan 8\% di antaranya menolak. 274 sisanya menyatakan ragu dengan rencana Pemerintah untuk mendistribusikan vaksin COVID19. Berdasarkan data responden yang dilakukan Kementerian Kesehatan bersama Indonesian Technical Advisory Group on Immunization (ITAGI) yang dirilis pada Oktober 2020, menununjukan bahwa masih ada sekitar 7,6 persen masyarakat yang menolak untuk divaksinasi dan 26,6 persen masyarakat belum memutuskan dan masih kebingungan.

Dari uraian tersebut di atas terihat jelas bahwa masih terdapat masyarakat yang tidak mau diberikan vaksinasi Covid-19 padahal hal ini merupakan upaya pemerintah dalam memberikan jaminan Kesehatan dan keselamatan bagi seluruh warganya.

\subsection{Perumusan Masalah}

Berdasarkan latar belakang di atas yang menjadi rumusan masalah dalam penelitian ini adalah sebagai berikut:

1. Bagaimana pengaturan sanksi bagi penolak vaksinasi Covid-19.

2. Bagaimana hak menolak vaksinasi Covid-19 ditinjau dari sudut pandang HAM.

\section{KAJIAN PUSTAKA}

\subsection{Sanksi}

Menurut Black's Law Dictionary, sanction (sanksi) adalah "a penalty or coercive measure that results from failure to comply with a law, rule, or order (a sanction for discovery abuse)" atau sebuah hukuman atau tindakan memaksa yang dihasilkan dari kegagalan untuk mematuhi undang-undang. Sedangkan pengertian sanksi menurut Kamus Besar Bahasa 
Indonesia merupakan tanggungan (tindakan atau hukuman) untuk memaksa orang menepati perjanjian atau menaati ketentuan undang-undang (anggaran dasar, perkumpulan, dan sebagainya); tindakan (mengenai perekonomian) sebagai hukuman kepada suatu negara hukum;

a. Imbalan negatif, berupa pembebanan atau penderitaan yg ditentukan dalam hukum;

b. Imbalan positif, yg berupa hadiah atau anugerah yg ditentukan dalam hukum.

Menurut Hans Kelsen, sanksi didefinisikan sebagai reaksi koersif masyarakat atas tingkah laku manusia (fakta sosial) yang mengganggu masyarakat. Setiap sistem norma dalam pandangan Hans Kelsen selalu bersandar pada sanksi. Esensi dari hukum adalah organisasi dari kekuatan, dan hukum bersandar pada sistem paksaan yang dirancang untuk menjaga tingkah laku sosial tertentu. Dalam kondisi-kondisi tertentu digunakan kekuatan untuk menjaga hukum dan ada sebuah organ dari komunitas yang melaksanakan hal tersebut. Setiap norma dapat dikatakan "legal" apabila dilekati sanksi, walaupun norma itu harus dilihat berhubungan dengan norma yang lainnya.

Jenis-Jenis Sanksi:

a. Sanksi Pidana

Bentuk hukuman Pidana diatur dalam Pasal 10 KUHP, yaitu:

1) Pidana Pokok, yang terbagi atas:

a) Pidana Mati;

b) Pidana Penjara;

c) Pidana Kurungan;

d) Pidana denda;

e) Pidana Tutupan.

2) Pidana Tambahan, yang terbagi atas:

a) Pencabutan hak-hak tertentu,

b) Perampasan barang-barang tertentu,

c) Pengumuman putusan hakim.

b. Sanksi Perdata

Bentuk sanksi hukum perdata dapat berupa kewajiban untuk memenuhi prestasi (kewajiban) dan atau hilangnya suatu keadaan hukum, diikuti dengan terciptanya suatu keadaan hukum baru.

c. Sanksi Administratif

Jenis Sanksi Administrasi dapat dilihat dari segi sasarannya yaitu:

1) Sanksi reparatoir, artinya sanksi yang diterapkan sebagai reaksi atas pelanggaran norma, yang ditujukan untuk mengembalikan pada kondisi semula sebelum terjadinya pelanggaran, misalnya bestuursdwang, dwangsom;

2) Sanksi punitif, artinya sanksi yang ditujukan untuk memberikan hukuman pada seseorang, misalnya adalah berupa denda administratif;

3) Sanksi regresif, adalah sanksi yang diterapkan sebagai reaksi atas ketidakpatuhan terhadap ketentuan yang terdapat pada ketetapan yang diterbitkan.

\subsection{Vaksinasi Covid-19}

Vaksin adalah produk biologi yang berisi antigen berupa mikroorganisme atau bagiannya atau zat yang dihasilkannya yang telah diolah sedemikian rupa sehingga aman, yang apabila diberikan kepada seseorang akan menimbulkan kekebalan spesifik secara aktif terhadap penyakit tertentu.

Vaksinasi adalah proses di dalam tubuh, dimana seseorang menjadi kebal atau terlindungi dari suatu penyakit sehingga apabila suatu saat terpajan dengan penyakit tersebut maka tidak akan sakit atau hanya mengalami sakit ringan, biasanya dengan pemberian vaksin.

Vaksinasi COVID-19 adalah bagian penting dari upaya penanganan pandemi COVID-

19 yang menyeluruh dan terpadu meliputi aspek pencegahan dengan penerapan protokol kesehatan: menjaga jarak, mencuci tangan pakai sabun dan memakai masker (3M), vaksinasi COVID-19, dan 3 T (Tes, Telusur, Tindak lanjut). 
Tujuan utama vaksinasi COVID-19 adalah mengurangi transmisi/penularan COVID19, menurunkan angka kesakitan dan kamatian akibat COVID-19. Mencapai kekebalan kelompok di masyarakat (herd imunity) dan melindungi masyarakat dari COVID-19 agar tetap produktif secara sosial dan ekonomi. Herd Immunity atau kekebalan kelompok akan terbentuk jika sebagian besar masyarakat divaksinasi. Cakupan vaksinasi yang tinggi membutuhkan partisipasi dan kerjasama berbagai pihak untuk mengatasi keengganan dan keraguan (hesitancy) masyarakat terhadap vaksinasi, meningkatkan penerimaan (acceptance) dengan memastikan ketersediaan akses pada informasi yang akurat tentang vaksinasi COVID-19.

Kelompok prioritas penerima vaksin adalah penduduk yang berdomisili di Indonesia yang berusia $\geq 18$ tahun. Kelompok penduduk berusia di bawah 18 tahun dapat diberikan vaksinasi apabila telah tersedia data keamanan vaksin yang memadai dan persetujuan penggunaan pada masa darurat (emergency use authorization) atau penerbitan nomor izin edar (NIE) dari Badan Pengawas Obat dan Makanan.

\section{METODE PENELITIAN}

Metode pendekatan yang digunakan dalam penelitian ini adalah pendekatan yuridis normatif dengan pengumpulan data sekunder yang diperoleh melalui kepustakaan dan peraturan perundang-undangan yang berhubungan dengan Covid-19. Peneliti memilih melakukan metode ini dengan pertimbangan karena situasi yang masih terkendala Covid-19 jika penelitian tersebut dilakukan dengan pendekatan empiris. Data yang diperoleh dari penelitian ini selanjutnya dianalisis secara kulitatif, yaitu untuk menjawab permasalahan tentang bagaimana pengaturan sanksi bagi penolak vaksinasi Covid-19, dan bagaimana hak menolak vaksinasi Covid-19 ditinjau dari sudut pandang HAM.

\section{HASIL DAN PEMBAHASAN}

\subsection{Pengaturan Sanksi Bagi Penolak Vaksinasi Covid-19}

a. UU Nomor 4 Tahun 1984 tentang Wabah Penyakit Menular

Pasal 14 ayat (1) menyebutkan bahwa, Barang siapa dengan sengaja menghalangi pelaksanaan penanggulangan wabah sebagaimana diatur dalam Undang-Undang ini, diancam dengan pidana penjara selama-lamanya 1 (satu) tahun dan/atau denda setinggi-tingginya Rp. 1.000.000,- (satu juta rupiah).

Pasal 14 ayat (1) menyebutkan bahwa, Barang siapa karena kealpaannya mengakibatkan terhalangnya pelaksanaan penanggulangan wabah sebagaimana diatur dalam Undang-Undang ini, diancam dengan pidana kurungan selama-lamanya 6 (enam) bulan dan/atau denda setinggi-tingginya Rp. 500.000,- (lima ratus ribu rupiah).

b. Peraturan Presiden (Perpres) Nomor 14 Tahun 2021 tentang Perubahan atas Perpres Nomor 99 Tahun 2020 tentang Pengadaan Vaksin_dan Pelaksanaan Vaksinasi dalam Rangka Penanggulangan Pandemi Covid-19

Pasal 13B menyebutkan bahwa, Setiap orang yang telah ditetapkan sebagai sasaran penerima Vaksin COVID- 19, yang tidak mengikuti Vaksinasi COVID-19 dan menyebabkan terhalangnya pelaksanaan penanggulangan penyebaran COVID- 19, selain dikenakan sanksi:

1) Penundaan atau penghentian pemberian jaminan sosial atau bantuan sosial;

2) Penundaan atau penghentian layanan administrasi pemerintahan; dan

3) Denda.

Dari uraian tersebut di atas, dapat ditarik kesimpulan bahwa sanksi bagi penolak vaksin Covid-19 yaitu berupa penjara 6 bulan sampai 1 tahun penjara atau denda Rp. 500.000,- (lima ratus ribu rupiah) sampai Rp. 1.000.000,- (satu juta rupiah). Selain itu juga terdapat sanksi yang berupa penundaan atau penghentian pemberian jaminan sosial atau bantuan sosial, penundaan atau penghentian layanan administrasi pemerintahan, dan denda.

\subsection{Hak Menolak Vaksinasi Covid-19 Ditinjau dari Sudut Pandang HAM}


Hak-hak manusia yang harus diakui sebagai hak-hak yang asasi warga negara dalam kehidupan berbangsa dan bernegara. Hak-hak asasi manusia pada konsepnya yang paling awal ini adalah hak-hak rakyat dalam kedudukan mereka sebagai manusia warga negara yang berkebebasan dalam suatu kehidupan bernegara bangsa yang demokratik.

Menurut Jimly Asshidiqqie, bahwa hak asasi manusia pada generasi pertama berkenaan dengan hak-hak sipil dan politik yang mencakup antara lain:

a. Hak untuk menentukan nasib sendiri,

b. Hak untuk hidup,

c. Hak untuk tidak dihukum mati,

d. Hak untuk tidak disiksa,

e. Hak untuk tidak ditahan secara sewenang-wenang,

f. Hak untuk peradilan yang adil, independen, dan tidak berpihak,

g. Hak untuk berekspresi atau menyampaikan pendapat,

h. Hak untuk berkumpul dan berserikat,

i. Hak untuk mendapatkan persamaan perlakuan di depan hukum,

j. Hak untuk memilih dan dipilih.

Menurut Jimly Asshidiqqie bahwa, Persoalan hak asasi manusia tidak cukup hanya dipahami dalam konteks hubungan kekuasaan yang bersifat vertikal, tetapi mencakup pula hubungan-hubungan kekuasaan yang bersifat horizontal, antar kelompok masyarakat, antara golongan rakyat atau masyarakat, dan bahkan antar satu kelompok masyarakat di suatu negara dengan kelompok masyarakat di negara lain.

Lebih lanjut tertuang pada:

a. UUD UUD 1945

Pasal 28I (1) menyebutkan bahwa, Hak untuk hidup, hak untuk tidak disiksa, hak kemerdekaan pikiran dan hati nurani, hak beragama, hak untuk tidak diperbudak, hak untuk diakui sebagai pribadi di hadapan hukum, dan hak untuk tidak dituntut atas dasar hukum yang berlaku surut adalah hak asasi manusia yang tidak dapat dikurangi dalam keadaan apa pun.

b. UU No. 29/1999 tentang HAM

Pasal 4 menyebutkan bahwa, Hak untuk hidup, hak untuk tidak disiksa, hak kebebasan pribadi, pikiran dan hati nurani, hak beragama, hak untuk tidak diperbudak, hak untuk diakui sebagai pribadi dan persamaan dihadapan hukum, dan hak untuk tidak dituntut atas dasar hukum yang berlaku surut adalah hak asasi manusia yang tidak dapat dikurangi dalam keadaan apapun dan oleh siapapun.

Jika kedua pasal di atas dikaitkan dengan Pasal 28J (1) yang menyatakan bahwa Setiap orang wajib menghormati hak asasi manusia orang lain dalam tertib kehidupan bermasyarakat, berbangsa, dan bernegara. Maka dapat diartikan bahwa Pemerintah juga harus siap menghormati setiap keputusan masyarakat yang menolak dilakukan vaksinasi Covid-19 terlepas dari segala pengaturan sanksi bagi penolak vaksinasi Covid-19. Kemudian jika mengacu pada teori HAM yang dikemukakan oleh Jimly Asshidiqqie bahwa setiap orang berhak untuk menentukan nasib sendiri, maka dapat diartikan bahwa menolak Vaksinasi Covid19 merupakan kebebasan individu yang tidak bisa dipaksakan.

Meninjau Pasal 14 ayat (1) UU No.4/1984, menyebutkan bahwa, Barang siapa dengan sengaja menghalangi pelaksanaan penanggulangan wabah sebagaimana diatur dalam UndangUndang ini, diancam dengan pidana penjara selama-lamanya 1 (satu) tahun dan/atau denda setinggi-tingginya Rp. 1.000.000,- (satu juta rupiah). Kata menghalangi tidak sama dengan menolak, karena istilah menghalangi menurut KBBI adalah merintangi atau menutupi. Seseorang yang menolak dilakukan vaksinasi Covid-19 bukanlah merupakan bentuk tindakan menghalangi program Pemerintah dalam pelaksanaan wabah melainkan hanya hak personal yang dengan segala pertimbangan untuk menyampaikan aspirasinya terhadap risiko dan konsekuensi terhadap tubuhnya. 
Meninjau Pasal 13B Peraturan Presiden (Perpres) Nomor 14 Tahun 2021 tentang Perubahan atas Perpres Nomor 99 Tahun 2020 tentang Pengadaan Vaksin_dan Pelaksanaan Vaksinasi dalam Rangka Penanggulangan Pandemi Covid-19, menyebutkan bahwa setiap orang yang telah ditetapkan sebagai sasaran penerima Vaksin COVID- 19, yang tidak mengikuti Vaksinasi COVID-19 dan menyebabkan terhalangnya pelaksanaan penanggulangan penyebaran COVID- 19, selain dikenakan sanksi:

1) Penundaan atau penghentian pemberian jaminan sosial atau bantuan sosial;

2) Penundaan atau penghentian layanan administrasi pemerintahan; dan

3) Denda.

Sungguh sangat kejam jika sanksi denda benar-benar dilaksanakan oleh Pemerintah, mengingat bahwa aspek sosial di sini tidak dipertimbangkan. Jika masyarakat golongan miskin dikenakan sanksi denda, apalagi yang bersangkutan juga telah kehilangan pekerjaanya akibat Covid-19 maka hal ini merupakan bentuk penjajahan gaya baru yang dilakukan oleh Pemerintah sendiri yang seharusnya mampu dalam melindungi warga negaranya. Padahal fungsi hukum di sini adalah selain untuk menciptakan keadilan juga bisa menciptakan lingkungan masyararakat yang aman dan tertib, dan untuk menciptakan kerukunan dan perdamaian dalam hidup bersama.

Peraturan dibuat untuk masyarakat, maka masyarakat itulah yang akan menentukan bisa atau tidaknya peraturan tersebut dijalankan. Jika memberhatikan terhadap hak-hak rakyat dalam kedudukan mereka sebagai manusia warga negara yang berkebebasan dalam suatu kehidupan bernegara bangsa yang demokratik, maka setidaknya Pemerintah mampu memberikan pilihan kepada masyarakat tentang Vaksinasi Covid-19 dan bukan malah menjerumuskan masyarakat dalam sanksi pidana maupun administrasi.

Dari uraian tersebut di atas, dapat ditarik kesimpulan bahwa menolak vaksinasi Covid19 merupakan bentuk kebebasan individu yang tidak bisa dipaksakan dengan segala pertimbangan untuk menyampaikan aspirasinya terhadap risiko dan konsekuensi terhadap tubuhnya. Di mana hal ini seharusnya dihormati oleh Pemerintah sebagaiana yang tertuang dalam Pasal 28J Ayat (1) UUD 1945.

\section{KESIMPULAN}

Berdasarkan hasil penelitian yang telah diuraikan di atas, dapat ditarik kesimpulan:

1. Bahwa sanksi bagi penolak vaksin Covid-19 yaitu berupa penjara 6 bulan sampai 1 tahun penjara atau denda Rp. 500.000,- (lima ratus ribu rupiah) sampai Rp. 1.000.000,- (satu juta rupiah). Selain itu juga terdapat sanksi yang berupa penundaan atau penghentian pemberian jaminan sosial atau bantuan sosial, penundaan atau penghentian layanan administrasi pemerintahan, dan denda.

2. Bahwa menolak vaksinasi Covid-19 merupakan bentuk kebebasan individu yang tidak bisa dipaksakan dengan segala pertimbangan untuk menyampaikan aspirasinya terhadap risiko dan konsekuensi terhadap tubuhnya. Di mana hal ini seharusnya dihormati oleh Pemerintah sebagaiana yang tertuang dalam Pasal 28J Ayat (1) UUD 1945.

\section{SARAN}

Selanjutnya, sebagaimana kesimpulan yang telah peneliti uraikan tersebut di atas, adapun saran dalam penelitian ini di antaranya:

1. Pemerintah Pusat perlu meninjau ulang pemberlakuan sanksi bagi masyarakat yang menolak vaksinasi Covid-19.

2. Pemerintah Daerah selaku pelaksana perlu melakukan diskusi terlebih dahulu dengan masyarakat terkait pemberian Vaksinasi Covid-19, dan tidak serta merta secara tegas langsung diberlakukan sanksi.

3. Pemerintah Desa perlu melakukan edukasi kepada masyarakat untuk meningkatkan pemahaman mereka tentang pentingnya Vaksinasi Covid-19 dengan segala jaminan apabila terjadi risiko maupun komplikasi Pasca Vaksinasi Covid-19. 


\section{DAFTAR PUSTAKA \\ Buku}

Abintoro Prakoso, 2018, Pengantar Hukum Indonesia, Yogyakarta: Laksbang Pressindo.

Achmad Sanusi, 1991, Pengantar Ilmu Hukum dan Pengantar Hukum Indonesia, Bandung: Tarsito.

Aris Prio Agus Santoso, 2020, Hukum Kesehatan, Jakarta: Trans Info Media.

Imam Gunawan, 2013, Metode Penelitian Kualitatif Teori dan Praktek, Jakarta: Bumi Aksara.

Inu Kencana Safiie, 2014, Ilmu Pemerintahan, Jakarta: Bumi Aksara.

Ishaq, 2017, Metode Penelitian Hukum Dan Penulisan Skripsi, Tesis, Serta Disertasi, Bandung: Alfabeta.

Ismail Nurdin, dan Sri Hartati, Surabaya: Media Sahabat Cendekia.

Jhonny Ibrahim, 2006, Teori dan Metodologi Penelitian Hukum Normatif, Edisi Revisi, Malang:

Bayumedia.

Kaelan, 2016, Pendidikan Kewarganegaraan, Yogyakarta: Paradigma.

Kemenkes RI, 2020, Faq Seputar Pelaksanaan Vaksinasi Covid-19, Jakarta: Kemenkes RI.

Komaruddin Hidayat dan Azyumardi Azra, 2008, Pendidikan Kewarganegaraan, Jakarta: Prenada

Media Group.

KPCPEN, 2020, Buku Saku Info Vaksin, Jakarta: KPCPEN.

------, 2021, Paket Vaksinasi Covid-19, Jakarta: KPCPEN.

Soetandyo Wignjosoebroto, 2007, Hak Asasi Manusia Konsep Dasar dan Perkembangan Pengertiannya Dari Masa Ke Masa, Jakarta: Lembaga Studi dan Advokasi Masyarakat.

\section{Jurnal}

Aris Prio Agus Santoso, "Legal Protection of Health Workers in the Task Force for the Acceleration of Handling Covid-19 from a State Administrative Law Point of View", Jurnal Ilmu Sosial dan Pendidikan, Vol. 5, No. 2, 2021.

Bambang Heri Supriyanto, "Penegakan Hukum Mengenai Hak Asasi Manusia (HAM) Menurut Hukum Positif di Indonesia”, Jurnal AL-Azhar Indonesia Seri Pranata Sosial, Vol. 2, No. 3, 2014.

B. Arief Sidharta, “Kajian Kefilsafatan tentang Negara Hukum”, Jurnal Hukum Jentera, Pusat Studi Hukum dan Kebijakan (PSHK) Jakarta, Vol. 3 No. 2, 2014.

Besar, "Pelaksanaan dan Penegakkan Hak Asasi Manusia dan Demokrasi di Indonesia", Jurnal: HUMANIORA Vol.2 No.1, 2011.

Brian Tamanaha, "The Concept of Rule of Law”, Jurnal Hukum Jentera, Pusat Studi Hukum dan Kebijakan (PSHK) Jakarta, Vol. 3 No. 2, 2004.

Didiek R. Mawardi, "Fungsi Hukum dalam Kehidupan Masyarakat”, Masalah-masalah Hukum, Vol. 44, No. 3, 2015.

Farina Gandryani, dan Fikri Hadi, "Pelaksanaan Vaksinasi Covid-19 di Indonesia: Hak Atau Kewajiban Warga Negara”, Jurnal Rechtsvinding, Vol. 10 No. 1, 2021.

Imas Novita Juaningsih, dkk, “Optimalisasi Kebijakan Pemerintah Dalam Penanganan Covid-19 Terhadap Masyarakat Indonesia", SALAM; Jurnal Sosial \& Budaya Syar-I, Vol. 7, No. 6, 2020.

Leo Agustino, "Analisis Kebijakan Penanganan Wabah Covid-19: Pengalaman Indonesia", Jurnal Borneo Administrator, Vol. 6, No. 2, 2020.

Mohammad Mulyadi, "Partisipasi Masyarakat dalam Penanganan Penyebaran Covid-19”, Jurnal Info Singkat, Vol. 12, No.8, 2020.

Noer Febriyanti1, dkk, "Hubungan Tingkat Pengetahuan dan Kesediaan Vaksinasi Covid-19 Pada Warga Kelurahan Dukuh Menanggal Kota Surabaya", Prosiding Seminar Nasional Hasil Riset dan Pengabdian Ke-III (SNHRP-III 2021).

\section{Peraturan}

RI, UUD 1945. 
RI, Undang-Undang Nomor 29 Tahun 1999 tentang Hak Asasi Manusia.

RI, Peraturan Presiden (Perpres) Nomor 14 Tahun 2021 tentang Perubahan atas Perpres Nomor 99 Tahun 2020 tentang Pengadaan Vaksin_dan Pelaksanaan Vaksinasi dalam Rangka Penanggulangan Pandemi Covid-19. 